\title{
ANALISA KOMPARATIF USAHA TANI PADI YANG MENGGUNAKAN PESTISIDA NABATI DAN PESTISIDA KIMIA (STUDI KASUS DI KELOMPOK TANI TIRTODIMULYO III DESA KLAMPOKAN KECAMATAN PANJI KABUPATEN SITUBONDO)
}

\author{
Listianah Rahmawati \\ Balai Penyuluhan Pertanian \\ Dinas Tanaman Pangan, Holtikulutura dan Perkebunan Situbondo \\ Email Korespondensi : lrahmawati@gmail.com
}

\begin{abstract}
Abstrak
Tujuan penelitian ini adalah (1) untuk mengkaji penerimaan, (2) untuk menganalisis pendapatan dan (3) menganalisis efisiensi usaha tani padi. Penelitian ini dilaksanakan di Desa Klampokan Kecamatan Panji. Metode pengumpulan data menggunakan wawancara langsung dan dokumentasi. Data yang diperoleh dianalisis secara deskriptif dan menggunakan uji independent sampel t test. Hasil penelitian menunjukkan bahwa terdapat perbedaan antara penerimaan usahatani yang menggunakan pestisida nabati dan pestisida kimia. Terdapat perbedaan antara pendapatan usahatani yang menggunakan pestisida nabati dan pestisida kimia. Kemudian, tidak terdapat perbedaan antara efisiensi usahatani padi yang menggunakan pestisida nabati dan pestisida kimia.
\end{abstract}

Kata Kunci : penerimaan, pendapatan, efisiensi

\begin{abstract}
This study analyzes (1) the revenue, (2) the income and (3) the efficiency of rice farming. This research was carried out in the village of Klampokan, Panji, Situbondo. The data were collected by using direct interviews and documentations. The data obtained were analyzed descriptively with the independent sample test. The results showed that there was a difference between the income of farming with organic pesticides and farming with chemical pesticides. The income of farmers who use organic pesticides differs from the income of farmers who use chemical pesticides. In terms of efficiency, there is no difference between rice farming with organic pesticides and that with chemical pesticides.
\end{abstract}

Keywords: revenue, income, efficiency

\section{PENDAHULUAN}

Pembangunan pertanian secara alami yang ramah lingkungan saat ini banyak dilakukan untuk menghasilkan bahan makanan yang aman, serta bebas dari bahan-bahan kimia yang berbahaya dan beracun. Untuk meningkatkan dan menjaga kestabilan produksi pertanian, khususnya tanaman pangan, sangat perlu diterapkan teknologi yang murah dan mudah bagi petani. Teknologi tersebut dituntut ramah lingkungan dan dapat memanfaatkan seluruh potensi sumberdaya alam yang ada di lingkungan pertanian, sehingga tidak memutus rantai sistem pertanian.

Penggunaan Secara umum pestisida nabati diartikan sebagai suatu pestisida yang bahan dasarnya adalah tumbuhan. Pestisida nabati relatif mudah dibuat dengan bahan dan teknologi yang sederhana. Bahan bakunya yang alami/nabati membuat pestisida ini mudah terurai (biodegradable) di alam sehingga tidak mencemari lingkungan. Pestisida ini juga relatif aman bagi manusia dan ternak peliharaan karena residunya mudah hilang. 
Pestisida nabati bersifat "pukul dan lari" (hit and run), saat diaplikasikan, akan membunuh hama saat itu juga dan setelah hamanya mati, residunya akan hilang di alam. Dengan demikian produk terbebas dari residu pestisda sehingga aman dikonsumsi manusia (Asmaliyah, dkk. 2010).

Pestisida nabati menjadi alternatif pengendalian hama yang aman dibanding pestisida sintetis. Penggunaan pestisida nabati memberikan keuntungan ganda, selain menghasilkan produk yang aman, lingkungan juga tidak tercemar. Pestisida organik ini mampu mengatasi dan mengusir hama perusak tanaman pertanian dan perkebunan umumnya seperti kutu, ulat, belalang dan sebagainya (Panut Djojosumarto, 2008).

Melihat fenomena seperti yang telah dipaparkan pada latar belakang pembuatan penelitian ini maka, dapat ditarik rumusan masalah yang ingin diangkat penulis yaitu :

1. Bagaimana perbedaan penerimaan usaha tani padi yang menggunakan pestisida nabati dan pestisida kimia (studi kasus) di kelompok tani Tirtodimulyo III Desa Klampokan Kecamatan Panji Kabupaten Situbondo.

2. Bagaimana perbedaan pendapatan usaha tani padi yang menggunakan pestisida nabati dan pestisida kimia (studi kasus) di kelompok tani Tirtodimulyo III Desa Klampokan Kecamatan Panji Kabupaten Situbondo.

3. Bagaimana perbedaan efisiensi penggunaan pestisida nabati dan pestisida kimia (studi kasus) di kelompok tani Tirtodimulyo III Desa Klampokan Kecamatan Panji Kabupaten Situbondo.

\section{METODE PENELITIAN}

Penelitian ini menggunakan deskriptif kuantitatif dengan bantuan perhitungan menggunakan microsoft office excel untuk membuktikan hipotesa adanya perbedaan produksi, pendapatan dan efisiensi (R/C rasio). Dari perbedaan deskriptif kuantitatif, dianalisis secara statistik menggunakan uji beda (Independent sample $t$ test) dengan bantuan program statistika SPSS ver. 15

Penelitian ini dilakukan di kelompok tani Tirtodimulyo III Desa Klampokan Kecamatan Panji Kabupaten Situbondo Provinsi Jawa Timur, dengan pertimbangan pertama bahwa desa Klampokan memiliki kelompok tani berprestasi tingkat Propinsi bidang pertanian. Semenjak tahun 2016 mulai melakukan penanaman padi organik khususnya penggunaan pestisida nabati hingga saat ini. Kelompok tani desa ini juga telah mengajukan sertifikasi organik melalui LSO Leysus pada awal tahun 2018. Pertimbangan kedua yaitu lokasi Desa Klampokan dengan rumah peneliti tidak terlalu jauh, sehingga pemilihan objek, lokasi dan waktu penelitian dilakukan secara sengaja (purposive). Waktu penelitian yaitu bulan Nopember 2018 sampai dengan bulan Januari tahun 2019.

Penelitian ini merupakan terdiri dari dua tahap. Tahap pertama yaitu dalam pencarian data primer dan tahap kedua yaitu pengambilan data sekunder.

Data primer diperoleh melalui pengamatan dan wawancara langsung terhadap responden (petani padi sawah) yang telah dipilih sebelumnya dengan menggunakan kuesioner. Sedangkan data sekunder digunakan untuk mendukung data primer. Data sekunder diperoleh dari berbagai instansi atau dinas serta media cetak yang berkaitan dengan masalah penelitian seperti Badan Pusat Statistik Kab. Situbondo, Dinas Tanaman Pangan Hortikultura Kab. Situbondo. Balai Penyuluhan Pertanian Kapongan, Penyuluh Pertanian Lapang Desa Klampokan, Kantor Desa Klampokan, Media online, informasi dan hasil penelitian serta tulisan yang berkaitan dengan penelitian.

Sampel dalam penelitian ini adalah petani padi sawah. Pemilihan petani responden dilakukan dengan sengaja (purposive) dengan menggunakan sistem sampel stratifkasi sederhana (purposive sampling). Populasi petani dibagi menjadi 2 kelompok, yaitu berdasarkan pengguna pestisida nabati dan pengguna pestisida kimia. Kemudian dari 
masing-masing kelompok tersebut diambil masing-masing 15 responden, sehingga total responden sebanyak 30 orang.

Metode analisis data yang diterapkan selaras dengan metode penelitian yang dignakan yaitu deskriptif kuantitatif. Analisis yang dilakukan adalah analisis penerimaan, pendapatan dan efisiensi (R/C rasio). Data yang diperoleh diolah dan disederhanakan dengan bantuan kalkulator dan komputer dengan menggunakan Microsoft Excel serta disajikan dalam bentuk tabulasi dan diuraikan secara deskriptif.

Untuk membuktikan hipotesis pertama tentang perbedaan penerimaan usahatani yang menggunakan pestisida nabati dan pestisida kimia maka data produksi ditabulasi menggunakan Microsoft Excel dan dicari jumlah total kemudian rata-rata (mean), standart deviasi, $\mathrm{t}$ tabel. Selanjutnya untuk membuktikan kebenaran hipotesis tersebut maka dilakukan uji t dengan rumus :

$$
t=\frac{x_{1}-x_{2}}{\sqrt{\left(\frac{\left(n_{1}-1\right) S^{2}{ }_{1}+\left(n_{2}-2\right) S_{2}^{2}}{n_{1}+n_{2}-2}\right)}\left(\frac{1}{n_{1}}+\frac{1}{n_{2}}\right)}
$$

Dimana : $\quad t \quad$ : Nilai yang dihitung

$\mathrm{X}_{1} \quad$ : Jumlah penerimaan rata-rata dengan pestisida nabati.

$\mathrm{X}_{2} \quad$ : Jumlah penerimaan rata-rata dengan pestisida kimia.

$\mathrm{S}_{1} \quad$ : Standart deviasi penerimaan dengan pestisida nabati

$\mathrm{S}_{2} \quad$ : Standart deviasi penerimaan dengan pestisida kimia

$\mathrm{n}_{1}$ dan $\mathrm{n}_{2} \quad$ : Jumlah sampel yang dibandingkan

Dari perhitungan statistik diatas maka sampel yang dibandingkan dengan nilai $\mathrm{t}$ pada tabel akan diambil keputusan dengan kriteria sebagai berikut :

1. Jika $t$ hitung $<\mathrm{t}$ tabel, berarti non signifikan atau tidak terdapat perbedaan nyata antara nilai-nilai yang diperbandingkan.

2. Jika t hitung $>t$ tabel, berarti signifikan atau terdapat perbedaan nyata antara nilainilai yang diperbandingkan.

Dasar pengambilan keputusan dengan uji independent sample t tes dengan SPSS sebagai berikut :

1. Jika nilai Sig. (2-tailed) $<0,05$ maka terdapat perbedaan yang signifikan antara nilainilai yang diperbandingkan.

2. Jika nilai Sig. (2-tailed) $>0,05$ maka tidak terdapat perbedaan yang signifikan antara nilai-nilai yang diperbandingkan.

Selanjutnya untuk menguji hipotesis kedua yaitu untuk mengetahui perbedaan pendapatan usahatani yang menggunakan pestisida nabati dan pestisida kimia maka dilakukan analisis pendapatan. Analisis digunakan untuk mengetahui besar pendapatan yang diterima petani. Sebelum menghitung pendapatan maka harus diketahui terlebih dahulu penerimaan yang diperoleh petani, serta total biaya yang dikeluarkan petani. Penerimaan adalah nilai yang diperoleh dari jumlah produksi dikalikan dengan harga jual. Rumus penerimaan adalah :

Keterangan :

$$
\Pi=\mathrm{TR}-\mathrm{TC}
$$

$\Pi=$ pendapatan usahatani

$\mathrm{TR}=$ total penerimaan usahatani (Total Revenue)

$\mathrm{TC}=$ total biaya produksi usahatani (Total Cost)

Untuk membuktikan hipotesis kedua tentang perbedaan pendapatan usahatani yang menggunakan pestisida nabati dan pestisida kimia maka data pendapatan ditabulasi menggunakan Microsoft Excel dan dicari jumlah total kemudian rata-rata (mean), standart 
deviasi, $\mathrm{t}$ tabel. Selanjutnya untuk membuktikan kebenaran hipotesis tersebut maka dilakukan uji $\mathrm{t}$

Pembuktian hipotesis ketiga yaitu untuk membandingkan efisiensi usahatani padi yang menggunakan pestisida nabati dan pestisida kimia., dapat dihitung dengan rumus sebagai berikut :

$$
E=\frac{T R}{T C}
$$

Keterangan: .

$\mathrm{E} \quad=$ Nilai efisiensi

TR $=$ Total Penerimaan

$\mathrm{TC}=$ Total biaya

Sedangkan untuk menguji kebenaran hipotesa tersebut tentang perbedaan efisiensi usahatani yang menggunakan pestisida nabati dan pestisida kimia maka data efisiensi ditabulasi menggunakan Microsoft Excel dan dicari jumlah total kemudian ratarata (mean), standart deviasi, t tabel. Selanjutnya untuk membuktikan kebenaran hipotesis tersebut maka dilakukan uji t.

\section{HASIL DAN PEMBAHASAN}

\section{Gambaran Umum Lokasi Penelitian}

Kecamatan Panji memiliki luas wilayah 46,990 Ha dengan ketinggian 36-104 mdpl. Curah hujan rata-rata 1112/tahun, dan jumlah hari dengan curah hujan terbanyak ialah 27 hari, dengan temperatur sekitar 19-20oC. Kecamatan Panji memiliki bentuk wilayah hamparan dataran rendah, dengan sedikit berbukit dengan kemiringan 45 derajat. Bentuk wilayah hamparan dataran rendah sekitar 75\%, dan 25\% sisanya berbukit.

Desa Klampokan memiliki luas areal wilayah sebesar 461 Ha dan berada pada ketinggian $104 \mathrm{~m}$ diatas permukaan air laut. Merupakan dataran tinggi dengan suhu rata-rata tahunan sekitar 28-320C. berikut:

Dilihat dari posisinya, Desa Klampokan dibatasi oleh wilayah-wilayah sebagai

a. Sebelah Utara : Desa Panji Kidul dan Desa Juglangan

b. Sebelah Selatan : Kabupaten Bondowoso

c. Sebelah Barat : Desa Battal

d. Sebelah Timur : Desa Kandang Kecamatan Kapongan

\section{Identitas responden}

Sebagian besar petani yang menggunakan pestisida nabati dan kimia berpendidikan rendah. Hal ini seperti yang ditunjukkan pada tabel 1, bahwa dari 15 responden pengguna pestisida nabati sebanyak 6 orang (40\%) tidak sekolah, lulus SD sebanyak 5 orang $(33,33 \%)$ dan lulus SMP sebanyak 4 orang $(26,66 \%)$.

Tabel 1. Pendidikan yang ditamatkan petani

\begin{tabular}{ccccc}
\hline \multirow{2}{*}{ Pendidikan } & \multicolumn{3}{c}{ NABATI } & \multicolumn{3}{c}{ KIMIA } \\
\cline { 2 - 5 } & Petani (org) & $(\%)$ & Petani (org) & $(\%)$ \\
\hline Tidak sekolah & 6 & 40 & 6 & 40 \\
\hline Lulus SD & 5 & 33,33 & 5 & 33,33 \\
\hline Lulus SMP & 4 & 26,66 & 4 & 26,66 \\
\hline Total & 15 & 100 & 15 & 100 \\
\hline
\end{tabular}


Sedanglan petani responden pengguna pestisida kimia sebanyak 15 orang terdiri dari 7 orang tidak sekolah $(46,66 \%), 3$ orang lulus SD (20\%) dan 5 orang lulus SMP $(33,33 \%)$. Dilihat dari dua (2) data primer tersebut diatas, maka responden pada penelitian ini memiliki tingkat pendidikan yang rendah. Tentunya secara logika akan berdampak pada tingkat serapan teknologi budidaya tanaman padi pada khususnya akan menjadi sulit untuk diterima.Petani cenderung untuk menggunakan metode bercocok tanam yang telah mereka peroleh dari turun temurun dan berakibat pada produktivitas yang stagnan bahkan menurun akibat serangan hama penyakit dan penggunaan pestisida yang tidak tepat sasaran.

Pengalaman bertani bagi responden tentu sangat berdampak pada produksi yang dihasilkan pada suatu budidaya tanaman padi. Berikut pengalaman bertani bagi responden pengguna pestisida nabati dan pestisida kimia di Desa Klampokan Kecamatan Panji Kabupaten Situbondo.

Tabel 2. Pengalaman bertani responden pestisida nabati dan kimia

\begin{tabular}{ccccc}
\hline \multirow{2}{*}{ Pengalaman bertani } & \multicolumn{2}{c}{ NABATI } & \multicolumn{2}{c}{ KIMIA } \\
\cline { 2 - 5 } & Petani $($ org $)$ & $(\%)$ & Petani $($ org) & $(\%)$ \\
\hline 1 tahun & 4 & 26,66 & - & - \\
2 tahun & 3 & 20 & - & - \\
\hline 3 tahun & 8 & 53,33 & - & - \\
\hline 6 tahun & - & - & 3 & 20 \\
\hline 7 tahun & - & - & 7 & 46,66 \\
\hline 8 tahun & - & - & 5 & 33,33 \\
\hline Total & 15 & 100 & 15 & 100 \\
\hline
\end{tabular}

Dilihat dari tabel 2 diatas, responden pengguna pestisida nabati memiliki persentase tertinggi pada mereka yang memiliki pengalaman bertani 3 tahun. Pada kriteria ini petani masih sangat terbuka terhadap inovasi. Mereka memiliki kecenderungan yang cukup tinggi untuk mencoba hal-hal baru. Sebaliknya, petani yang memiliki pengalaman bertani lama lebih sulit menerima inovasi karena mereka memiliki pengetahuan bertani yang lebih lama sehingga lebih tertutup terhadap perubahan.

Umur petani responden berpengaruh pada tingkat pendapatan petani itu sendiri. Berikut kisaran umur petani pengguna pestisida nabati dan pestisida kimia di Desa Klampokan Kecamatan Panji Kabupaten Situbondo.

Tabel 3. Umur responden pestisida nabati dan kimia

\begin{tabular}{ccccc}
\hline \multirow{2}{*}{ Umur } & \multicolumn{2}{c}{ NABATI } & \multicolumn{2}{c}{ KIMIA } \\
\cline { 2 - 5 } & Petani (org) & $(\%)$ & Petani (org) & $(\%)$ \\
\hline 30 tahun & 3 & 20 & 3 & 20 \\
$31-49$ tahun & 9 & 60 & 7 & 46,66 \\
\hline 50 tahun & 3 & 20 & 5 & 33,33 \\
\hline Total & 15 & 100 & 15 & 100 \\
\hline
\end{tabular}

Umur berkorelasi positif dengan serapan teknologi karena semakin muda maka semakin mudah untuk menerima suatu perubahan atas kemajuan sarana informasi teknologi, sehingga akan meningkatkan produktivitas usaha taninya. Hal tersebut sesuai dengan pendapat Simanjuntak (2001) menyatakan bahwa semakin tinggi tingkat umur, maka semakin menurun kualitas kinerja seseorang dan berpengaruh menurun pula pada produktivitas. Hal tersebut seharusnya menjadi dorongan untuk para petani yang masih berusia muda agar lebih meningkatkan produktivitasnya, karena pada umumnya usia muda ( $25 \mathrm{~s} / \mathrm{d} 50$ tahun) masih tergolong usia yang produktif. 
Luas lahan garapan reponden baik yang menggunakan pestisida nabati dan pestisida kimia di Desa Klampokan Kecamatan Panji Kabupaten Situbondo antara 0,1 hektar hingga 0,3 hektar seperti yang ditunjukkan pada tabel dibawah, dimana untuk responden pengguna pestisida nabati yang menggarap sawah antara 0,1 sebanyak 2 petani $(13,33 \%)$, responden dengan luasan 0,2 hektar sebanyak 10 orang $(66,66 \%)$ dan responden dengan luasan 0,3 hektar sebanyak 3 orang (20\%).

Tabel 4. Luas lahan responden pestisida nabati dan kimia

\begin{tabular}{ccccc}
\hline \multirow{2}{*}{ Luas lahan (Ha) } & \multicolumn{2}{c}{ NABATI } & \multicolumn{2}{c}{ KIMIA } \\
\cline { 2 - 5 } & Petani (org) & $(\%)$ & Petani (org) & $(\%)$ \\
\hline 0,1 & 2 & 13,33 & 3 & 20 \\
0,2 & 10 & 66,66 & 9 & 60 \\
\hline 0,3 & 3 & 20 & 3 & 20 \\
\hline Total & 15 & 100 & 15 & 100 \\
\hline
\end{tabular}

Sedangkan responden yang menggunakan pestisida kimia dengan luas lahan antara 0,1 hektar sebanyak 3 orang (20\%), responden dengan luas lahan 0,2 hektar sebanyak 9 orang $(60 \%)$ dan responden dengan luas lahan 0,3 hektar sebanyak 3 orang $(20 \%)$.

Kepemilikan lahan responden penelitian terbesar 0,2 Ha. Ini artinya bahwa petani rata-rata memiliki lahan yang sempit sehingga kurang optimal dalam menghasilkan produksi yang besar. Karena setiap tahun kepemilikan lahan sawah akan berkurang karena diwariskan/diberikan pada ahli waris, dijual atau berubah fungsi lahan menjadi pekarangan/tempat tinggal. Hal tersebut sesuai dengan pendapat Daniel (2002) yang menyatakan bahwa luas lahan pertanian merupakan salah satu faktor produksi yang sangat penting dalam proses usahatani, serta lahan yang sempit sudah pasti kurang efisien dibanding lahan yang lebih luas. Semakin sempit lahan usaha, semakin tidak efisien usaha tani yang dilakukan.

\section{Penerimaan Usahatani Dengan Menggunakan Pestisida Nabati dan Pestisida kimia}

Penerimaan adalah hasil perkalian dari jumlah produksi total dengan harga produk. Penerimaan usahatani padi sawah dengan menggunakan pestisida nabati dan pestisida kimia disajikan pada tabel di bawah ini :

Tabel 5. Produksi rata-rata per hektar usahatani padi sawah dengan menggunakan pestisida nabati dan pestisida kimia, di Desa Klampokan Kec. Panji Kabupaten Situbondo Tahun 2018.

\begin{tabular}{cccc}
\hline \multirow{2}{*}{ Jenis Pestisida } & \multicolumn{3}{c}{ Produksi rata-rata $(\mathrm{Kg} / \mathrm{Ha})$} \\
\cline { 2 - 4 } & Minimum & Maksimum & Rata-rata \\
\hline Pestisida Nabati & 4850 & 6493 & 5608 \\
\hline Pestisida Kimia & 5150 & 6410 & 6000 \\
\hline Selisih & 300 & 83 & 392 \\
\hline
\end{tabular}

Dari tabel di atas dapat dilihat bahwa pada produksi usahatani padi sawah dengan menggunakan pestisida nabati minimum $4850 \mathrm{~kg} / \mathrm{Ha}$, maksimum $6493 \mathrm{~kg} / \mathrm{Ha}$ dan ratarata $5608 \mathrm{~kg} / \mathrm{Ha}$. Sedangkan produksi usahatani padi sawah dengan menggunakan pestisida kimia minimum $5150 \mathrm{~kg} / \mathrm{Ha}$, maksimum $6410 \mathrm{~kg} / \mathrm{Ha}$ dan rata-rata $6000 \mathrm{~kg} / \mathrm{Ha}$ dengan selisih produksi rata-rata usahatani padi sawah dengan mengggunakan pestisida nabati dan pestisida kimia adalah $392 \mathrm{~kg} / \mathrm{Ha}$.

Dari uraian di atas dapat dikatakan bahwa produksi usahatani padi sawah dengan menggunakan pestisida nabati dan pestisida kimia rata-rata produksi lebih tinggi menggunakan pestisida kimia daripada pestisida nabati namun dengan margin angka yang tidak terlalu jauh. 


\section{Biaya usahatani padi sawah}

Biaya usahatani padi sawah disajikan pada tabel di bawah ini :

Tabel 6. Biaya rata-rata per hektar usahatani padi sawah dengan menggunakan pestisida nabati dan pestisida kimia, di Desa Klampokan Kecamatan Panji Kabupaten Situbondo Tahun 2018

\begin{tabular}{cccc}
\hline \multirow{2}{*}{ Jenis Pestisida } & \multicolumn{3}{c}{ Biaya rata-rata (Rp/Ha) } \\
\cline { 2 - 4 } & Minimum & Maksimum & Rata-rata \\
\hline Pestisida Nabati & $8.874 .450,-$ & $12.755 .000,-$ & $10.034 .977,-$ \\
\hline Pestisida Kimia & $7.552 .500,-$ & $15.300 .000,-$ & $9.827 .540,-$ \\
\hline Selisih & $1.321 .950,-$ & $2.545 .000,-$ & $207.437,-$ \\
\hline
\end{tabular}

Berdasarkan tabel di atas dapat dilihat bahwa biaya usahatani padi sawah dengan menggunakan pestisida nabati minimum Rp. 8.874.450, maksimum Rp. 12.755.000,- dan rata-rata Rp. 10.034.977,--

Sedangkan biaya dengan menggunakan pestisida kimia minimum Rp. 7.552.500,-, maksimum Rp. 15.300.000,- dan rata-rata Rp. 9.827.540,-

Serta selisih biaya rata-rata usahatani dengan menggunakan pestisida nabati dan pestisida kimia adalah Rp. 207.437,--

Dari uraian di atas dapat dikatakan bahwa biaya usahatani padi sawah dengan menggunakan pestisida nabati dan pestisida kimia rata-rata biaya lebih tinggi menggunakan pestisida nabati daripada pestisida kimia namun lagi-lagi dengan margin angka yang tidak terlalu jauh.

\section{Penerimaan usahatani padi sawah}

Penerimaan usahatani padi sawah dengan menggunakan pestisida nabati dan pestisida kimia disajikan pada tabel di bawah ini :

Tabel 7. Penerimaan rata-rata per hektar usahatani padi sawah dengan menggunakan pestisida nabati dan pestisida kimia, di Desa Klampokan Kecamatan Panji Kabupaten Situbondo Tahun 2018.

\begin{tabular}{cccc}
\hline \multirow{2}{*}{ Jenis Pestisida } & \multicolumn{3}{c}{ Penerimaan rata-rata (Rp/Ha) } \\
\cline { 2 - 4 } & Minimum & Maksimum & Rata-rata \\
\hline Pestisida Nabati & $28.130 .000,-$ & $37.659 .400,-$ & $32.525 .627,-$ - \\
\hline Pestisida Kimia & $24.720 .000,-$ & $30.768 .000,-$ & $28.800 .320,-$ \\
\hline Selisih & $3.410 .000,-$ & $6.891 .400,-$ & $3.725 .307,--$ \\
\hline
\end{tabular}

Berdasarkan tabel di atas dapat dilihat bahwa penerimaan usahatani padi sawah dengan menggunakan pestisida nabati minimum Rp. 28.130.000,-. Hal ini terjadi karena produktivitas padi $4850 \mathrm{Kg} / \mathrm{Ha}$ GKS dengan harga jual per Kg Rp. 5800,-. Penerimaan maksimum sebesar Rp. 37.659.400,-. Hal ini disebabkan karena produktivitas padi sebesar $6493 \mathrm{Kg} / \mathrm{Ha}$ GKS dengan harga jual per Kg Rp. 5800,-. Untuk rata-rata penerimaan pestisida nabati sebesar Rp. 32.525.627,- dengan produksi rata-rata $5608 \mathrm{Kg} / \mathrm{Ha}$ GKS dengan harga jual per Kg sebesar Rp.5800,-

Sedangkan penerimaan dengan menggunakan pestisida kimia minimum $\mathrm{Rp}$. 24.720.000,-. Hal ini terjadi karena produktivitas padi $5150 \mathrm{Kg}$ GKS dengan harga jual per Kg Rp. 4800,-. Penerimaan maksimum Rp. 30.768.000,- Hal ini disebabkan karena produktivitas padi sebesar $6410 \mathrm{Kg} / \mathrm{Ha}$ GKS dengan harga jual per Kg Rp. 4800 dan untuk penerimaan rata-rata Rp. 28.800.320,- dengan produksi rata-rata $6000 \mathrm{Kg} / \mathrm{Ha}$ GKS dengan harga jual per Kg sebesar Rp.4800,-

Jadi dapat disimpulkan bahwa penerimaan usaha tani yang menggunakan pestisida nabati lebih menguntungkan daripada yang menggunakan pestisida kimia dilihat dari produksi dan harga jual per Kg gabah karena usahatani yang menggunakan pestisida 
nabati lebih ramah lingkungan dan lebih organik, sehingga memiliki nilai tawar yang lebih tinggi dari gabah yang menggunakan pestisida kimia.

Berarti dapat disimpulkan bahwa terdapat perbedaan rata-rata penerimaan padi sawah menggunakan pestisida nabati dan pestisida kimia. Untuk membuktikan apakah ada perbedaan yang nyata, menggunakan uji independent te-test.

Berdasarkan hasil analisis uji beda Independent Sample T-Test penerimaan usahatani padi menggunakan pestisida nabati dan pestisida kimia sebagai berikut:

Tabel 8. Hasil uji $\mathrm{T}$ untuk Perbedaan penerimaan usahatani padi sawah dengan menggunakan pestisida nabati dan pestisida kimia, di Desa Klampokan Kecamatan Panji Kabupaten Situbondo Tahun 2018

\begin{tabular}{ccc}
\hline Uraian & Sig.(2-tailet) & Tingkat kepercayaan 95\% $(\alpha)$ \\
\hline Pestisida Nabati & 0,00 & 0,05 \\
Pestisida Kimia & & \\
\hline
\end{tabular}

Berdasarkan tabel di atas untuk perbedaan penerimaan usahatani padi sawah dengan menggunakan pestisida nabati dan pestisida kimia, dimana nilai Sig. (2-tailed) yaitu $0,00<0,05$, maka H0 ditolak dan Ha diterima artinya terdapat perbedaan yang signifikan/nyata penerimaan usahatani padi sawah dengan menggunakan pestisida nabati dan pestisida kimia pada tingkat kepercayaan 95\%.

Penerimaan usahatani padi sawah yang menggunakan pestisida nabati lebih tinggi di bandingkan dengan usahatani padi sawah yang menggunakan pestisida kimia, hal ini terjadi karena harga penjualan padi menggunakan pestisida nabati lebih tinggi daripada pestisida kimia. Masyarakat sudah mulai sadar akan bahaya dari residu pestisida selain berdampak pada kesehatan manusia dalam jangka waktu yang lama, juga mencemari / merusak lingkungan di sekitar sawah. Hal itulah yang mendasari mengapa nilai harga jual padi yang menggunakan pestisida nabati lebih mahal dibandingkan padi dengan menggunakan pestisida kimia. Hal ini sesuai pernyataan Adrian, K (2018) bahwa pestisida merupakan zat kimia yang digunakan untuk mengendalikan hama, namun efek pestisida tidak hanya berpengaruh pada hama tetapi juga berbahaya bagi kesehatan manusia. Pestisida yang masuk ke tubuh manusia akan merusak sel tubuh dan mengganggu fungsi organ tubuh. Iritasi mata, iritasi kulit, kesulitan bernafas, pusing, sakit kepala, mual dan muntah bisa langsung dirasakan oleh mereka-mereka yang dalam aktivitasnya bersentuhan langsung dengan pestisida kimia. Paparan pestisida dalam dosis tinggi bahkan dapat menyebabkan kematian. Jika digunakan dalam jangka panjang, paparan pestisida beresiko menimbulkan beberapa masalah kesehatan seperti gangguan reproduksi, gangguan kehamilan dan janin, penyakit parkinson, kanker dan masih banyak lagi efek yang ditimbulkan dari bahaya residu pestisida kimia.

\section{Pendapatan usahatani padi sawah}

Pendapatan usaha tani merupakan sisa pengurangan nilai masing-masing penerimaan usaha tani dengan biaya yang dikeluarkan. Pendapatan usahatani padi sawah dengan menggunakan pestisida nabati dan pestisida kimia disajikan pada tabel di bawah ini :

Tabel 9. Pendapatan rata-rata per hektar usahatani padi sawah dengan menggunakan pestisida nabati dan pestisida kimia, di Desa Klampokan Kecamatan Panji Kabupaten Situbondo Tahun 2018

\begin{tabular}{cccc}
\hline \multirow{2}{*}{ Jenis Pestisida } & \multicolumn{3}{c}{ Pendapatan rata-rata (Rp/Ha) } \\
\cline { 2 - 4 } & Minimum & Maksimum & Rata-rata \\
\hline Pestisida Nabati & $17.704 .000,-$ & $27.985 .750,-$ & $22.490 .649,-$ \\
\hline Pestisida Kimia & $11.868 .000,-$, & $21.801 .000,-$ & $18.972 .780,-$ \\
\hline Selisih & $5.836 .000,-$ & $6.184 .750,-$ & $3.517 .869,-$. \\
\hline
\end{tabular}


Berdasarkan tabel di atas dapat dilihat bahwa pendapatan usahatani padi sawah dengan menggunakan pestisida nabati minimum Rp 17.704.000,-. Hal ini disebabkan karena penerimaan yang diperoleh Rp. 28.130.000,- dengan biaya total yang dikeluarkan sebesar Rp. 8.874.450,-. Pendapatan maksimum Rp. 27.985.750,. Hal ini disebabkan karena penerimaan yang diperoleh Rp. 37.659.400,- dengan biaya total yang dikeluarkan sebesar Rp. 12.755.000,-. Kemudian pendapatan rata-rata Rp. 22.490.649,-. Hal ini disebabkan karena penerimaan yang diperoleh Rp. 32.525.627,- dengan biaya total yang dikeluarkan sebesar Rp. 10.034.977,-.

Sedangkan pendapatan dengan menggunakan pestisida kimia minimum Rp. 11.868.000,-. Hal ini disebabkan karena penerimaan yang diperoleh Rp. 24.720.000,dengan biaya total yang dikeluarkan sebesar Rp. 7.552.500,- Pendapatan maksimum Rp. 21.801.000,- Hal ini disebabkan karena penerimaan yang diperoleh $\mathrm{Rp} 30.768 .000$,dengan biaya total yang dikeluarkan sebesar Rp. 15.300.000,- dan pendapatan rata-rata Rp. 18.972.780,- hal ini disebabkan karena penerimaan yang diperoleh Rp. 28.800.320,dengan biaya total yang dikeluarkan sebesar Rp. 9.827.540,-

Dari uraian di atas dapat disimpulkan bahwa pendapatan usahatani yang menggunakan pestisida nabati lebih menguntungkan daripada usahatani yang menggunakan pestisida kimia. Hal ini sesuai dengan pendapat Dewi Ratnasari (2015) bahwa bagi petani penggunaan pestisida nabati memang sangat menguntungkan, yaitu dapat memberantas hama secara mudah dan murah, dapat menurunkan populasi hama secara cepat dan dapat menekan kehilangan hasil karena hama. Dengan pestisida nabati petani juga tidak memerlukan tenaga yang banyak dan tidak memerlukan waktu dan biaya yang begitu besar. Dan tanpa pestisida tanaman yang dihasilkan tidak begitu memuaskan dan hasil produksinya pun kurang karena mereka sudah tergantung dengan pestisida.

Berarti dapat disimpulkan bahwa terdapat perbedaan rata-rata pendapatan padi menggunakan pestisida nabati dan pestisida kimia. Untuk membuktikan apakah ada perbedaan yang nyata, menggunakan uji independent te-test.

Berdasarkan hasil analisis uji beda Independent Sample T-Test pendapatan usahatani padi menggunakan pestisida nabati dan pestisida kimia sebagai berikut :

Tabel 10. Hasil uji T untuk Perbedaan pendapatan usahatani padi sawah dengan menggunakan pestisida nabati dan pestisida kimia, di Desa Klampokan Kecamatan Panji Kabupaten Situbondo Tahun 2018

\begin{tabular}{ccc}
\hline Uraian & Sig.(2-tailet) & Tingkat kepercayaan 95\% $(\alpha)$ \\
\hline Pestisida Nabati & 0,003 & 0,05 \\
Pestisida Kimia & & \\
\hline
\end{tabular}

Berdasarkan tabel di atas untuk perbedaan pendapatan usahatani padi sawah dengan menggunakan pestisida nabati dan pestisida kimia, dimana nilai Sig. (2-tailed) yaitu $0,003<0,05$, maka $\mathrm{HO}$ ditolak dan Ha diterima artinya terdapat perbedaan yang signifikan/nyata pendapatan usahatani padi sawah dengan menggunakan pestisida nabati dan pestisida kimia pada tingkat kepercayaan 95\%.

Pendapatan usahatani padi sawah yang menggunakan pestisida nabati lebih tinggi di bandingkan dengan usahatani padi sawah yang menggunakan pestisida kimia, hal ini terjadi karena harga penjualan padi menggunakan pestisida nabati lebih tinggi daripada pestisida kimia. Masyarakat sudah mulai sadar akan bahaya dari residu pestisida selain berdampak pada output hasil produksi pertanian dalam jangka waktu yang lama, juga mencemari / merusak lingkungan di sekitar sawah. Hal ini sesuai Laba et all (1998) bahwa penggunaan pestisida dalam proses produksi pertanian juga mengakibatkan timbulnya residu pestisida pada hasil pertanian. Residu pestisida dapat terjadi pada tanaman (daun, 
buah, cabang, akar, kulit \& sebagainya), tanah dan air yang selanjutnya dapat membahayakan kesehatan masyarakat.

Apabila petani direkomendasikan untuk mengurangi atau tidak menggunakan pestisida, maka yang paling diuntungkan adalah konsumen akan tetapi konsumen ternyata masih mengutamakan penampilan produk daripada keterbebasannya dari pestisida. Hal ini juga merupakan salah satu hambatan dalam melaksanakan penanaman padi non pestisida. Hal ini sesuai pendapat Kartaatmadja \& Sabri (1995) bahwa, Produk pertanian yang bebas dari pestisida seharusnya lebih tinggi nilainya. Nilai lebih ini akan merupakan insentif bagi petani yang menerapkan PHT.

Kemudian karena ketersediaan padi non pestisida ini dalam jumlah terbatas dan permintaan yang banyak jelas akan berdampak pada harga. Sesuai hukum ekonomi bahwa semakin banyak penawaran sedangkan ketersediaan sedikit harga akan naik. Itulah mengapa pendapatan petani pengguna pestisida nabati lebih tinggi harga jualnya daripada pestisida kimia. Hal ini sesuai Soekartawi (2002) yang menyatakan bahwa pendapatan usahatani juga dapat didefinisiskan sebagai sisa dari pengurangan nilai penerimaan yang diperoleh dari biaya yang dikeluarkan.

Kesimpulan yang ditunjukkan bahwa bahwa terdapat perbedaan yang signifikan pendapatan usahatani padi sawah yang menggunakan pestisida nabati dan pestisida kimia.

\section{Efisiensi Usahatani Padi Sawah Dengan Menggunakan Pestisida nabati dan Pestisida kimia}

Hasil analisa R/C rasio usahatani padi sawah dengan menggunakan pestisida nabati dan pestisida kimia disajikan pada tabel di bawah ini :

Tabel 11. Efisiensi usahatani padi sawah dengan menggunakan pestisida nabati dan pestisida kimia, di Desa Klampokan Kecamatan Panji.

\begin{tabular}{cccc}
\hline Jenis Pestisida & $\begin{array}{c}\text { Penerimaan } \\
(\mathrm{Rp})\end{array}$ & Biaya ( Rp ) & $\mathrm{R} / \mathrm{C}$ \\
\hline Pestisida Nabati & $32.525 .627,-$ & $10.034 .977,-$ & 3,24 \\
\hline Pestisida Kimia & $28.800 .320,-$ & $9.827 .540,-$ & 2,93 \\
\hline
\end{tabular}

$\mathrm{R} / \mathrm{C}$ rasio dapat diketahui dari hasil pembagian antara total penerimaan dengan total biaya. Dari tabel di atas dapat dilihat bahwa nilai $\mathrm{R} / \mathrm{C}$ rasio usahatani padi sawah dengan menggunakan pestisida nabati 3,24 sedangkan nilai $\mathrm{R} / \mathrm{C}$ rasio usahatani padi sawah dengan menggunakan pestisida kimia 2,93, sehingga dengan menggunakan kedua jenis pestisida tersebut sama-sama efisien. Namun usahatani padi sawah dengan menggunakan pestisida nabati lebih efisien daripada usahatani padi sawah dengan menggunakan pestisida kimia. Artinya usahatani padi sawah dengan menggunakan pestisida nabati lebih menguntungkan (secara finansial) daripada usahatani padi sawah dengan menggunakan pestisida kimia. Berarti dapat disimpulkan bahwa tidak terdapat perbedaan rata-rata efisiensi padi menggunakan pestisida nabati dan pestisida kimia. Untuk membuktikan apakah tidak terdapat perbedaan yang nyata, menggunakan uji independent te-test. 
Berdasarkan hasil analisis uji beda Independent Sample T-Test efisiensi usahatani padi menggunakan pestisida nabati dan pestisida kimia sebagai berikut :

Tabel 12. Hasil uji $\mathrm{T}$ untuk Perbedaan efisiensi usahatani padi sawah dengan menggunakan pestisida nabati dan pestisida kimia, di Desa Klampokan Kecamatan Panji Kabupaten Situbondo Tahun 2018

\begin{tabular}{cccc}
\hline Jenis Pestisida & R/C & Sig.(2-tailet) & Tingkat kepercayaan 95\% $(\alpha)$ \\
\hline Nabati & 3,24 & 0,148 & 0,05 \\
\hline Nabati & 2,93 & 0,148 & \\
\hline
\end{tabular}

Berdasarkan tabel di atas untuk perbedaan efisiensi usahatani padi sawah dengan menggunakan pestisida nabati dan pestisida kimia, dimana nilai Sig. (2-tailed) yaitu 0,148 > 0,05, , maka H0 diterima dan Ha ditolak artinya tidak terdapat perbedaan yang signifikan efisiensi usahatani padi sawah dengan menggunakan pestisida nabati dan pestisida kimia pada tingkat kepercayaan 95\%.

Tingkat efisiensi usahatani padi sawah yang menggunakan pestisida nabati dapat menghasilkan produksi yang lebih efisiensi di bandingkan dengan usahatani padi sawah yang menggunakan pestisida kimia, hal ini terjadi dikarenakan hasil pembagian antara total penerimaan dan total biaya produksi menggunakan pestisida nabati. Total penerimaan dan total biaya produksi usahatani padi sawah yang menggunakan pestisida nabati dan pestisida kimia dapat dilihat pada hasil penelitian di atas (tabel 6 dan tabel 7). Sehingga dapat dilihat bahwa nilai Sig. (2-tailed) yaitu 0,148 >0,05, artinya tidak terdapat perbedaan yang signifikan efisiensi usahatani padi sawah dengan menggunakan pestisida nabati dan pestisida kimia dikarenakan lokasi penelitian masih dalam fase konversi menuju organik. Poktan Tirtodimulyo III Desa Klampokan Kecamatan Panji Kab. Situbondo baru memulai gerakan padi sehat dengan aplikasi pestisida nabati dimulai semenjak tahun 2016 hingga sekarang. Kemungkinan lainnya lokasi masih tercemar oleh residu pestisida atau hal hal non organik lainnya dari petak sawah non organik.

Kesimpulan yang ditunjukkan bahwa bahwa tidak terdapat perbedaan yang signifikan efisiensi usahatani padi sawah yang menggunakan pestisida nabati dan pestisida kimia.

\section{KESIMPULAN}

1) Terdapat perbedaan antara penerimaan usahatani yang menggunakan pestisida nabati dan pestisida kimia.

2) Terdapat perbedaan antara pendapatan usahatani yang menggunakan pestisida nabati dan pestisida kimia.

3) Tidak terdapat perbedaan antara efisiensi usahatani padi yang menggunakan pestisida nabati dan pestisida kimia.

\section{REFERENSI}

Asmaliyah, dkk. 2010. Pengenalan Tumbuhan Penghasil Pestisida Nabati Dan Pemanfaatannya Secara Tradisional. Badan Litbang Kehutanan. Kementerian Kehutanan. Jakarta.

Panut Djojosumarto, 2008. Pestisida dan Aplikasinya. PT. Agromedia Pustaka. Jakarta.

Setiawati W, dkk. 2008. Tumbuhan bahan pestisida nabati. Pusat penelitian dan pengembangan hortikultura. Kementerian Pertenian. Jakarta.

Suratiyah Ken 2008. Ilmu Usahatani. Penebar Swadaya. Jakarta 